\title{
Faktor Resiko Jatuh pada Lansia di Unit Pelayanan Primer Puskesmas Medan Johor
}

\author{
Vitri Rohima, Iwan Rusdi, Evi Karota* \\ Fakultas Keperawatan, Universitas Sumatera Utara, Medan, Indonesia \\ *)E-mail: evi_karota@yahoo.com
}

\begin{abstract}
ABSTRAK
Latar Belakang: Lansia merupakan tahap akhir pertumbuhan kehidupan manusia yang mengalami perubahan fisik maupun psikososial, dan salah satu aspek penting perubahan itu adalah resiko jatuh. Resiko jatuh pada lansia dipengaruhi oleh faktor intrinsik, faktor ekstrinsik, dan faktor situasional. Tujuan: penelitian ini untuk mengetahui hubungan resiko jatuh dengan kejadian jatuh pada klien lansia di Puskesmas Medan Johor. Metode: Penelitian ini merupakan studi deskriptif korelasi terhadap 70 responden lansia. Pengumpulan data dilakukan dengan menggunakan kuisioner faktorfaktor penyebab resiko jatuh dan kejadian resiko jatuh pada klien lansia. Hasil: umumnya klien berusia 60-74 (51\%), beragama Islam (81\%), dan keluarga tinggal serumah lebih dari 2 orang $84 \%$. Hasil penelitian menunjukkan faktor penyebab resiko jatuh lansia terutama dari faktor situasional $26 \%$, faktor intrinsik $17 \%$ dan tidak ada dari faktor ekstrinsik $(0 \%)$. Berdasarkan kejadian resiko jatuh pada lansia adalah $46 \%$ beresiko tinggi, $36 \%$ beresiko rendah, dan $18 \%$ tidak beresiko. Hasil uji chi square menunjukkan adanya hubungan yang signifikan dari faktor intrinsik $p=0,000$, faktor ekstrinsik $p=0,000$ dan faktor situasional $p=0,004$ terhadap kejadian resiko jatuh. Kesimpulan: faktor-faktor resiko jatuh berhubungan dengan kejadian jatuh pada klien lansia di Puskesmas Medan Johor. Hasil penelitian ini dapat menjadi masukan bagi pelayanan kesehatan khususnya pelayanan asuhan keperawatan untuk meningkatkan edukasi kepada klien lansia dan keluarganya tentang dengan resiko jatuh dan pelayanan kesehatan dapat melakukan pengembangan program kegiatan pencegahan resiko jatuh pada lansia.
\end{abstract}

Kata Kunci: Lansia, resiko jatuh, kejadian resiko jatuh

\section{Risk for Full Factor among the Elders in Puskesmas Medan Johor}

\section{ABSTRACT}

Background: Elderly is a process of human life experiencing various physical and psychosocial changes, and one important aspect due to these changes is the risk of falling among the elders. It is influenced by intrinsic, extrinsic, and situational factors. Aim: The purpose of this study was to determine the relationship between the risk of falls and the incidence of falls in elderly clients who visit to the Health Center. Method: This study is a descriptive study of correlation to 70 elderly people at the Puskesmas Medan Johor. The data were collected by using questionnaires of risk factors of fall and risk incidence of falls on the elders. Result: Demographic data are generally the elders aged 60-74 years (51\%), Moslem (81\%), family live at home more than 2 person (84\%). The results of the study showed that the risk factor of falling elderly mainly from situational factor (26\%), intrinsic factor (17\%) and extrinsic factor (0\%). Meanwhile, based on the risk incidence of falling on the elderly clients, the result is high risk (46\%), low risk (36\%), and no risk of fall $(18 \%)$. The chi square test shows that there is significant correlation of intrinsic factor $p=0.000$, extrinsic factor $p=0.000$ and situational factor $p=0.004$ to fall risk event. Conclusion: There is a relationship between falling risk factors and the incidence of falls in elderly clients at the Puskesmas Medan Johor. This study provide recommendations for health services, especially nursing care services to provide education to elderly clients and their families related to the risk of falls in the elderly and the health centers can develop prevention programs to reduce the risk of falls in the elderly.

Keywords: Elderly, a risk factor for falling, the risk of falling 


\section{LATAR BELAKANG}

Menjadi tua merupakan suatu fase kehidupan yang dilalui oleh setiap manusia. Seiring dengan pertambahan usia maka fungsi organ-organ tubuh akan mengalami kemunduran, baik secara fisik maupun psikologis. Perubahan fisik pada lanjut usia (lansia) akibat penurunan fungsi organ tubuh secara degenerative berdampak terhadap kesehatan dan aktivitas lansia sehari-hari. Masalah kesehatan yang dialami yaitu penyakit diabetes melitus, hipertensi, pernafasan, gastritis, rheumatoid arthritis, daya tahan tubuh menurun, mata rabun, pendengaran menurun, dan masalah psikososial lainnya (Darmojo \& Martono, 2009; National Institute on Aging, 2017).

Peningkatan resiko jatuh pada Lansia terus meningkat. Kongres XII PERSI 2012 melaporkan bahwa kejadian pasien jatuh di Indonesia bulan Januari-September 2012 sebesar 14\% (Departemen Kesehatan Republik Indonesia/Depkes RI, 2008). Kejadian resiko jatuh meningkat seiring pertambahan usia dengan kejadian usia lebih dari 65 tahun sebesar $30 \%$ dan pada pasien lebih dari 80 tahun mencapai $50 \%$ (Mupangati, 2018). Jatuh sering kali dialami para lansia yang disebabkan beberapa faktor, yaitu faktor intrinsik berupa penyakit yang diderita terutama semua penyakit dalam, digestif, endokrin, gangguan penglihatan, sistem anggota gerak, gangguan sistem saraf pusat, penyakit sistemik dan efek dari terapi obat-obatan yang digunakan. Faktor ekstrinsik dapat diidentifikasi dari kondisi lingkungan tinggal lansia yaitu penggunaan alat bantu berjalan, lingkungan rumah turun tangga, lantai licin, penerangan kurang, toilet jauh dari kamar, kondisi ruang tidak ergonomis, tempat tidur terlalu tinggi/rendah (Miller, 1999; Darmojo \& Martono, 2009).

Faktor situasional dapat didentifikasi dari riwayat penyakit yang diderita klien
6 bulan terkhir, serta aktivitas sehari-hari yang biasa dilakukan seperti naik turun tangga, berolahraga, dan aktifitas lain. Hal ini situasi yang umum dialami lansia berupa penurunan fungsi organ fisik. Perubahan ini mengakibatkan kelambatan bergerak, gangguan keseimbangan dan koordinasi gerak sehingga mudah jatuh. Selain itu faktor gizi juga sangat berpengaruh terhadap keseimbangan lansia (Kementerian Kesehatan Republik Indonesia, 2010; Mauk, 2010).

Insiden jatuh pada lansia dapat menyebabkan cedera jaringan lunak dan fraktur paha, pergelangan tangan dan bahkan kematian. Selain itu, juga dapat menyebabkan masalah lain, yaitu nyeri, keterbatasan mobilisasi, ketidaknyamanan fisik, dan proses penyembuhan yang lambat sehingga berdampak pada kondisi lansia, terutama mereka yang mengalami ketergantungan dalam aktivitas sehari-hari.

\section{METODE}

Penelitian ini adalah penelitian deskriptif korelasi yang bertujuan untuk mengetahui faktor-faktor berhubungan dengan resiko jatuh pada Lansia di Puskesmas Medan Johor. Penetapan jumlah sampel 20\% dari jumlah populasi yaitu: 70 orang (Dempsey \& Dempsey, 2010). Penelitian ini menggunakan teknik purposive sampling sesuai kriteria inklusi: lansia berusia 55 tahun, mampu mengingat dan melakukan arahan, dapat berkomunikasi dengan baik dalam Bahasa Indonesia, tidak mengalami disorientasi waktu, tempat, dan orang, bersedia menjadi responden penelitian.

Uji validitas instrumen dilakukan dosen pakar di bidang ilmu keperawatan gerontik dari Fakultas Keperawatan Universitas Sumatera Utara, sedangkan uji reliabilitas dilakukan terhadap 20 orang lansia berbeda dengan sampel penelitian, menggunakan analisis KR-21. Hasil uji reliabilitas adalah 
73 sehingga instrumen layak digunakan.

Analisis data dilakukan secara univariat untuk mendeskripsikan data demografi dan analisis data bivariat menggunakan uji chisquare untuk mengetahui hubungan faktorfaktor resiko jatuh dengan kejadian resiko jatuh.

Izin peneltian dari pimpinan Fakultas Keperawatan Universitas Sumatra Utara, dan pimpinan Dinas Kesehatan Kota Medan. Persetujuan Komisi Etik Penelitian Kesehatan FKep USU No.756/III/SP/2016.

\section{HASIL}

Hasil penelitian pada tabel 1. menunjukkan umumnya responden perempuan (56\%), usia $60-74$ tahun (51\%), dan beragama Islam $(81 \%)$. Berdasarkan tingkat pendidikan, terbanyak SMA (33\%), menikah (84\%), hubungan keluarga dengan lansia mayoritas jumlah anggota keluarga $>2$ orang $(84 \%)$.

Tabel 1. Distribusi frekuensi dan persentase karakteristik klien Lansia di Unit Pelayanan Puskesmas Medan Johor $(n=70)$

\begin{tabular}{lll}
\hline Karakteristik & $\mathbf{f}$ & $\mathbf{\%}$ \\
\hline Usia (tahun) & & \\
- $45-59$ & 31 & 44 \\
- $60-74$ & 36 & 52 \\
- $75-90$ & 3 & 4 \\
$\begin{array}{l}\text { Jenis Kelamin } \\
\text { - Laki-laki }\end{array}$ & 31 & 44 \\
- Perempuan & 39 & 56 \\
Agama & & \\
- Islam & 57 & 81 \\
- Protestan & 9 & 13 \\
- Katolik & 4 & 6 \\
Pendidikan & & \\
- SD & 16 & 22 \\
- SMP & 11 & 16 \\
- SMA & 23 & 33 \\
- PT & 20 & 29 \\
Status & & \\
- Menikah & 59 & 84
\end{tabular}

\begin{tabular}{lll}
\hline Karakteristik & $\mathbf{f}$ & $\%$ \\
\hline - Duda/Janda & 16 & 23 \\
Keluarga serumah & & \\
- Tidak Ada & 2 & 3 \\
- 1-2 Orang & 9 & 13 \\
- >2 orang & 59 & 84 \\
\hline
\end{tabular}

Pada tabel 2, faktor resiko jatuh klien lansia di Puskesmas Medan Johor adalah faktor intrinsik $(17 \%)$, faktor situasional (26\%), faktor ekstrinsik (0\%).

Tabel 2. Faktor- Faktor Penyebab Terjadinya Resiko Jatuh pada Klien Lansia di Unit Pelayanan Puskesmas Medan Johor ( $n=70)$

\begin{tabular}{|c|c|c|}
\hline Karakteristik & $f$ & $\%$ \\
\hline \multicolumn{3}{|l|}{ Faktor Intrinsik } \\
\hline Beresiko & 12 & 17 \\
\hline Tidak Beresiko & 58 & 83 \\
\hline \multicolumn{3}{|c|}{ Faktor } \\
\hline \multicolumn{3}{|l|}{ Ekstrinsik } \\
\hline Beresiko & 0 & 0 \\
\hline Tidak Beresiko & 0 & 0 \\
\hline \multicolumn{3}{|c|}{ Faktor Situasional } \\
\hline Beresiko & 18 & 26 \\
\hline Tidak Beresiko & 52 & 74 \\
\hline
\end{tabular}

Hasil penelitian pada tabel 3. menunjukkan bahwa kejadian resiko jatuh pada klien Lansia di pelayanan Puskesmas Medan Johor umumnya beresiko tinggi $(46 \%)$, beresiko rendah $(36 \%)$, dan tidak beresiko jatuh $(18 \%)$.

Tabel 3. Kejadian resiko jatuh pada klien Lansia yang datang berobat ke Unit Pelayanan Puskesmas Medan Johor $(n=70)$

\begin{tabular}{lcc}
\hline Kejadian Resiko Jatuh & f & $\%$ \\
\hline Tidak beresiko (0-24) & 13 & 18 \\
Beresiko rendah (25-50) & 25 & 36 \\
Beresiko tinggi $(>50)$ & 32 & 46 \\
\hline
\end{tabular}


Tabel 4 menunjukkan terdapat hubungan yang signifikan antara faktor-faktor resiko jatuh dengan kejadian resiko jatuh. Faktor penyebab kejadian resiko jatuh adalah faktor intrinsik dengan hasil $p=0,000$, faktor ekstrinsik dengan nilai $p=0,000$, dan faktor situasional dengan nilai $p=0,004$.

Tabel 4. Hubungan faktor resiko jatuh dengan resiko kejadian jatuh pada klien Lansia di Unit Pelayanan Puskesmas Medan Johor $(n=70)$

\begin{tabular}{lll}
\hline Faktor Resiko Jatuh & \multicolumn{2}{l}{ Kejadian resiko jatuh } \\
\hline & Value (df) & Asy. sig \\
\hline
\end{tabular}

Faktor intrinsik (0-24)

Faktor ekstrinsik (25-50)

$59,71(22) \quad 0,000$

Faktor situasional $(>50)$
$33,02(10) \quad 0,000$ $28,67(12) \quad 0,004$

\section{DISKUSI}

Hasil penelitian menunjukkan 17\% lansia yang berobat ke Puskesmas Medan Johor beresiko jatuh dari faktor intrinsik, yang diidentifikasi semua lansia terdiagnosis hipertensi, gangguan sistem anggota gerak, gangguan sistem syaraf, gangguan penglihatan, dan gangguan pendengaran. Hal ini mengindikasikan bahwa penyakit yang diderita lansia beresiko terjadi jatuh.

Studi sebelumnya menjelaskan bahwa lansia memiliki resiko tinggi terjatuh. Dilaporkan ada sebanyak $70 \%$ lansia (18 responden) mengalami resiko jatuh dengan dengan kategori tinggi pada kondisi seiring peningkatan usia (Af'idah, Dewi, \& Hadhisuyatmana, 2012). Hal yang sama dengan data yang ditunjukkan dalam penelitian ini yaitu pada tabel 1 bahwa ada $52 \%$ lansia berusia $60-74$ tahun dan sebahagian dari mereka beresiko terjatuh dari faktor situasional $26 \%$ (tabel 2). Hal ini memungkinkan secara fisik bahwa lansia memiliki resiko jatuh yang tinggi disebabkan oleh proses menua yang terjadi pada lansia, terjadi perubahan pada kontrol postural yang memegang peran penting sebagian besar kejadian jatuh (Darmojo \& Martono, 2004).

Perubahan komponen biomekanik meliputi letensi mioelektik, waktu bereaksi, propioseptif, lingkup gerak sendi dan kekuatan otot memengaruhi resiko jatuh. Selain itu terdapat perubahan pada postur tubuh, gaya berjalan, sistem sensorik, dan mobilitas fungsional (Lueckenotte, 2000). Usia lanjut dikaitkan dengan proses degeneratif pada sistem vestibuler, refleks posisi melambat dan melemahnya kekuatan otot sangat penting mempertahankan postur. Keseimbangan dapat pula terganggu oleh karena adanya penyakit dan obat-obatan. Semua perubahan tersebut dapat berperan untuk terjadinya jatuh, terutama pada kemampuan untuk mencegah terjadinya jatuh manakala terpeleset atau menghadapi situasi lingkungan yang membahayakan (Miller, 1999; Wolfson, 2002).

Berdasarkan hasil penelitian ini dapat diindikasikan bahwa adanya faktor resiko jatuh pada klien lansia dari faktor intrinsik. Lansia di Puskesmas Medan Johor mengalami gangguan hipertensi sebanyak 38 orang $(54 \%)$ dari 70 Lansia beresiko jatuh. Selanjutnya penelitian yang hampir sama juga dilaporkan bahwa gangguan jantung merupakan gangguan kehilangan oksigen dan makanan ke jantung karena aliran darah ke jantung melalui arteri koroner berkurang yang mengakibatkan kelemahan dan berkurangnya keseimbangan. Penyakit jantung pada lanjut usia ditandai dengan seringnya merasakan nyeri pada daerah prekordial dan sesak nafas yang mengakitbatkan rasa cepat lelah dan biasanya terjadi di tengah malam. Gejala lainnya adalah kebingungan, muntahmuntah, dan nyeri pada perut karena pengaruh dari bendungan hepar, keluhan insomnia (Darmojo \& Martono, 2004).

Gangguan jantung pada lansia seperti 
hipertensi dimana tekanan darah sistolik sama atau lebih tinggi dari $140 \mathrm{mmHg}$ dan tekanan diastolik lebih tinggi dari 90 $\mathrm{mmHg}$, yang terjadi karena menurunnya elastisitas arteri pada proses menua. Bila tidak ditangani, hipertensi dapat memicu terjadinya stroke, kerusakan pembuluh darah, serangan/gagal jantung sehingga dapat menyebabkan kejadian jatuh pada lansia (Budhi-Darmojo, Martono, \& Hadi 2000).

Berdasarkan faktor ekstrinsik hasil penelitian ini menunjukkan bahwa 100\% lansia tidak memiliki resiko jatuh. Hal ini didukung oleh data yang diperoleh bahwa umumnya lansia tidak menggunakan alat bantu berjalan seperti kruk, walker, kaki palsu, kursi roda, walaupun ada sebahagian diantaranya menggunakan tongkat atau dipapah keluarga bila diperlukan. Hasil ini berbeda dengan penelitian terdahulu bahwa lansia yang menggunakan alat bantu berjalan dan kondisi lingkungan juga beresiko jatuh.

Hasil penelitian Achmanagara \& Andriyani (2012) menunjukkan terdapat 12 responden (25\%) yang beresiko jatuh menggunakan alat bantu berjalan. Penggunaan alat bantu berjalan membantu meningkatkan keseimbangan. Namun disisi lain alat bantu menyebabkan langkah terputus dan tubuh cenderung membungkuk. Karena itu penggunaan alat bantu seperti ini harus direkomendasi secara individual.

Ketika memilih alat bantu berjalan, anatomi tubuh dan sudut siku harus diperhatikan karena banyak dari mereka yang tidak dapat bantuan profesional dalam memilih alat bantu berjalan sehingga mengakibatkan bertambah buruknya gaya berjalan sehingga dapat memicu resiko jatuh (Darmojo \& Martono, 2004). Penelitian pada lansia di Tehran Hospital menunjukkan bahwa faktor lingkungan yang kurang baik merupakan salah satu penyebab resiko jatuh pada lansia dimana terdapat $72,3 \%$ (125 responden) lansia beresiko jatuh (Jamebozorgi, dkk, 2013).

Menurut Suhartini (2004), di Jawa Timur sebagian besar lansia yang tidak melakukan kegiatan aktivitas olahraga atau aktivitas kebugaran lainnya 73,1\% mengalami resiko tinggi jatuh. Hal ini disebabkan penurunan fungsi dan kekuatan otot tubuh karena kurangnya gerakan atau aktivitas yang dilakukan lansia.

Sebagian besar resiko jatuh terjadi saat lansia melakukan aktivitas sehari-hari seperti berjalan, naik turun tangga, dan mengganti posisi. Jatuh juga terjadi pada saat lansia melakukan aktivitas berbahaya seperti menaiki tangga atau olahraga berat. Kelelahan juga menyebabkan resiko jatuh dan jatuh juga sering terjadi pada lansia immobile (jarang bergerak) ketika tiba-tiba ingin berpindah tempat atau mengambil sesuatu (Martono \& Pranarka, 2009).

Hasil penelitian ini menunjukkan kejadian resiko jatuh pada klien lansia di Puskesmas Medan Johor 46\% responden yang mengalami resiko tinggi jatuh dan $36 \%$ lainnya beresiko rendah kejadian jatuh. Hasil penelitian ini hampir sama dengan penelitian yang dilakukan dengan pemeriksaan Dynamic Gait Index (DGI) yang menunjukkan bahwa sebagian besar lansia di Panti Werdha Hargodedali Surabaya berisiko tinggi terhadap kejadian jatuh (Af'idah, Dewi, \& Hadhisuyatmana, 2012).

Insiden gangguan gerak bertambah seiring bertambahnya usia. Hal tersebut dapat diakibatkan oleh proses penuaan itu sendiri atau karena penggunaan obatobatan yang menjadi pencetus terjadinya gangguan gerak (Miller, 2004). Hal ini sesuai dengan studi terdahulu yang dilakukan oleh Tinetti, dkk (1994) di USA bahwa lebih dari $30 \%$ pasien lansia yang berusia di atas 65 tahun mengalami insiden jatuh setiap tahunnya. 
Gangguan anggota gerak memicu terjadinya perubahan keseimbangan pada lansia. Gangguan keseimbangan dapat disebabkan oleh faktor penuaan, kecelakaan, mengantuk, obat-obatan dan penyakit yang diderita. Namun diantaranya proses penuaan adalah faktor utama penyebab gangguan keseimbangan postural pada lansia (National Institute on Aging, 2017).

Hasil penelitian menunjukkan bahwa terdapat hubungan antara faktor resiko jatuh dengan kejadian jatuh. Hasil uji chisquare penyebab kejadian jatuh adalah faktor intrinsik $p=0,000$, faktor ekstrinsik $p=0,000$, dan faktor situasional $p=0,004$. Hal yang sama disampaikan dalam penelitian Af'idah, Dewi, dan Hadhisuyatmana (2012) tentang prediksi risiko jatuh berdasarkan penilaian DGI di Surabaya menunjukkan umumnya responden berisiko jatuh tinggi sebanyak 18 responden (70\%). Masih dalam penelitian yang sama kejadian jatuh yang terjadi pada 14 dari 26 lansia di Panti Werdha Hargodedali dalam 3 bulan terakhir frekuensinya sebanyak $>3$ kali.

Berdasarkan hasil penelitian tentang keseimbangan tubuh lansia terdapat 30 responden yang tidak mengikuti senam lansia secara rutin. Rata-rata keseimbangan tubuh didapatkan nilai 24,63 dengan kategori risiko jatuh sedang. Hal ini mengindikasikan bahwa secara umum lansia yang tidak mengikuti senam secara teratur memiliki risiko jatuh lebih tinggi dibandingkan dengan yang mengikuti senam lansia secara teratur. Kondisi ini erat kaitannya dengan perubahan fisiologi lansia bahwa perubahan fungsi organ beresiko terjadinya jatuh (Lueckenotte, 2000). Perubahan pada lansia penting untuk diperhatikan, karena insiden jatuh berisiko lebih tinggi ketika lansia mengalami gangguan keseimbangan, gangguan berjalan, gangguan kognitif, penyakit diabetes, hipertensi, persendian
(National Institute on Aging, 2017; Miller, 1999).

Keterbatasan penelitian ini tidak dilakukan pemeriksaan fisik klinis lanjutan dan uji laboratorium untuk identifikasi faktor fisik akibat penyakit yang diderita berpengaruh terhadap resiko jatuh lansia.

\section{SIMPULAN}

Karakteristik lansia beresiko jatuh mengalami gangguan: hipertensi, sistem anggota gerak, syaraf, penglihatan, dan gangguan pendengaran. Penyebab faktor intrinsik (17\%), faktor ekstrinsik (0\%), dan faktor situasional beresiko jatuh (26\%), karena lingkungan rumah memiliki anak tangga dan benda di lantai menimbulkan lansia tersandung. Kejadian resiko jatuh pada klien lansia, yaitu: beresiko tinggi jatuh $(46 \%)$, beresiko jatuh rendah $(36 \%)$, tidak beresiko jatuh (18\%). Hasil uji Chi Square ada hubungan antara faktor resiko jatuh dengan kejadian jatuh signifikansi faktor intrinsik $p=0,000$, ekstrinsik $p=0,000$, faktor situasional $p=0,004$.

Pelayanan kesehatan dapat melakukan pengkajian awal untuk pemeriksaan prediksi resiko jatuh pada lansia, khususnya dengan masalah penurunan fungsi tubuh. Memberi edukasi dan latihan keseimbangan postural dinamik melalui senam lansia sebagai upaya pencegahan kejadian jatuh pada lansia.

\section{DAFTAR PUSTAKA}

Achmanagara, A. \& Andriyani. (2012). Hubungan Faktor Internal dan Eksternal dengan Keseimbangan Lansia di Desa Pamijen Sokaraja Banyumas. Jakarta: Balai Penerbit UI.

Af'idah, F.S.N., Dewi, Y.S., \& Hadhisuyatmana, S. (2012). Studi Risiko Jatuh Melalui Pemeriksaan Dynamic Gait Index (DGI) Pada Lansia di Panti Werdha Surabaya. Indonesian Journal of Community Health 
Nursing, 1(1):1-13. http://dx.doi. org/10.20473/ijchn.v1i1.11899

Budhi-Darmojo, R., Martono., \& Hadi. (2000). Beberapa Masalah Penyakit Pada Usia Lanjut. Jakarta: Balai Penerbit FKUI.

Darmojo, R.B. \& Martono, H.H. (2004). Geriatri (IImu Kesehatan Usia Lanjut). Jakarta: Penerbit FKUI.

Dempsey, P.A. \& Dempsey, A. D. (2010). Riset Keperawatan: Buku Ajar dan Latihan (Ed.1). (Alih bahasa: Budi, E \& Rika, I). Jakarta: EGC.

Departemen Kesehatan R.I. (2008). Panduan Nasional Keselamatan Pasien Rumah Sakit. Jakarta: Bhakti Husada.

Jamebozorgi, A. A., Kavoosi, A., Shafiee, Z., Kahlaee, A, H., \& Raei, M. (2013). Investigation of the prevalent FallRelated Risk Factors of Fractures in Elderly to Tehran Hospitals. Medical journal of Islamic Republic of Iran, 27(1): 23-30.

Kementerian Kesehatan Republik Indonesia. (2010). Pedoman Pembinaan Kesehatan Lanjut Usia Bagi Petugas Kesehatan. Jakarta: Direktorat Bina Kesehatan Komunitas.

Lueckenotte, A.G. (2000). Gerontologic Nursing. USA: Mosby.

Martono, H. \& Pranarka, K. (2009). Buku Ajar Boedhi-Darmojo: (IImu Kesehatan Usia Lanjut). Jakarta: FKUI.

Mauk. (2010). Gerontological Nursing Competencies for Care ( $\left.2^{\text {nd }} \mathrm{Ed}\right)$. Sudbury: Janes and Barlrtt Publisher.
Miller, C. A. (1999). Nursing care of older adults: theory and practice. Philadepia: Lippincott.

Miller, C. A. (2004). Nursing for Wellness in Older Adults: Theory and practice $\left(4^{\text {th }}\right.$ ed). Philadelphia: Lippincott Williams \& Wolkins.

Mupangati, Y.M. (2018). Jatuh pada Lansia. Retrieved from http://www.yankes. kemkes.go.id/read-jatuh-pada-lansia-4088.html

National Istitute on Aging. (2017). Prevent falls and fractures. Retrieved from https://www.nia.nih.gov/health/prevent-falls-and-fractures

Suhartini, R. (2004). Faktor-faktor yang mempengaruhi kemandirian orang lanjut usia. Bandung: Pustaka Setia.

Tinetti, M.E., Baker, D.I., McAvay, G., Claus, E.B., Garrett, P., Gottschalk M., Koch M.L., Trainor K., \& Horwitz R. I. (1994). A Multifactorial intervention to reduce the risk of Falling among elderly people living in the community. The New England Journal of Medicine, 331(13). Doi:10.1056/ NEJM199409293311301

Wolfson, L. (2002). Balance decrements in older persons: Effects of age and disease. In: Masdeu JC, Sudarsky L, Wolfson Dynamic Gait Index in people with vestibular disorders. Arch Phys Med Rehabil, 84: 15281533. 